\title{
Keterlibatan WALHI dalam Politik Lingkungan Hidup terhadap Kasus Kabut Asap di Riau
}

\author{
Herry Wahyudi \\ Program Studi IImu Hubungan Internasional \\ Universitas Abdurrab, Pekanbaru - Riau, Indonesia \\ Email: herry.wahyudi@univrab.ac.id \\ M Fajar Anugerah \\ Program Studi Ilmu Pemerintahan \\ Universitas Abdurrab, Pekanbaru - Riau, Indonesia \\ Email: fajar.anugerah@univrab.ac.id \\ Muhammad Arif \\ Program Studi Ilmu Komunikasi \\ Universitas Abdurrab, Pekanbaru, Riau, Indonesia \\ Email: muhammad.arif@univrab.ac.id
}

\begin{abstract}
Abstrak
Penelitian ini menelaah keterlibatan WALHI dalam politik lingkungan hidup terhadap kasus kabut asap di Riau dengan menggunakan sudut pandang WALHI sebagai organisasi nonpemerintah (NGO) yang banyak memberikan pengaruh dalam proses pengambilan kebijakan oleh pemerintah terhadap isu-isu lingkungan, khususnya di Riau pada saat bencana kabut asap. Ada upaya penggunaan relasi kekuasaan oleh WALHI sebagai organisasi non-pemerintah (NGO) melalui konsep kesempatan politik (political opportunity) dalam mengangkat isu bencana kabut asap di Riau sehingga menjadi isu lingkungan dalam lingkup internasional. Strategi advokasi transnasional (transnational advocacy) digunakan oleh WALHI Riau untuk memperlihatkan garis relasi kekuasaannya sebagai organisasi nonpemerintah (NGO) untuk memengaruhi kebijakan pemerintah daerah provinsi Riau terkait bencana kabut asap. Mulai dari strategi (1) information politics, yaitu kemampuan dalam menghasilkan informasi dan mengarahkan dampak yang akan terjadi dari informasi yang didapat. (2) symbolic politics, yakni kemampuan dalam menyerukan simbol maupun aksi yang dapat memunculkan opini publik dan framing serta konstruksi suatu isu, (3) leverage politics, merupakan kemampuan dalam memengaruhi situasi tertentu pada saat salah satu pihak tidak mampu memberikan pengaruh, dan (4) accountability politics, adalah usaha dalam mempertahankan aktor yang berkuasa agar tetap memegang kebijakan yang telah ditetapkan.
\end{abstract}

Kata Kunci: WALHI, Organisasi Non-Pemerintah (NGO), kabut asap Riau, politik lingkungan hidup, kesempatan politik (political opportunity), advokasi transnasional

\begin{abstract}
This research examines WALHI's involvement in environmental politics in the hazing case in Riau by using WALHI's perspective as a non-governmental organization (NGO) that has a lot of influence in the process of policymaking by the government on environmental issues, especially in Riau during haze disasters. There is an effort to use the power relations by WALHI as a non-governmental organization (NGO) through the concept of political opportunity in raising the issue of the haze disaster in Riau so that it becomes an environmental issue on an international scale. The transnational advocacy strategy was used by Walhi Riau to show the line of power relations as a non-governmental organization (NGO) to influence the policies of the Riau provincial government related to the haze disaster. Starting from the strategy (1) information politics, which is the ability to produce
\end{abstract}


information and direct the impact that will occur from the information obtained. (2) symbolic politics, namely the ability to call symbols and actions that can bring public opinion and framing and construction of an issue, (3) leverage politics, is the ability to influence certain situations when one party is unable to exert influence, and (4) accountability politics, is an effort to keep the powerful actors to keep upholding the policies that have been set.

Keywords: WALHI, Non-Governmental Organizations (NGOs), Riau's haze, environmental politics, political opportunities, transnational advocacy.

DOI: 10.36341/jdp.v4i2.1659

\section{PENDAHULUAN}

Provinsi Riau merupakan provinsi yang kaya akan minyak bumi dan sumber daya alam, terutama perkebunan kelapa sawit yang merupakan tumbuhan yang bisa hidup di lahan gambut. Terletak di pesisir Timur pulau Sumatera, provinsi ini juga menyumbang sebagai besar penyebaran perkebunan kelapa sawit dan lahan gambut di Indonesia. Daerah Provinsi Riau terdiri dari 9 kabupaten (Kuantan Singgingi, Indragiri Hulu, Indragiri Hilir, Pelalawan, Siak, Kampar, Rokan Hulu, Bengkalis dan Rokan Hilir) dan dua kotamadya yaitu Kota Pekanbaru dan Kota Dumai.

\section{Gambar 1. Peta Penyebaran Lahan Gambut di Riau Berdasarkan Kedalaman}

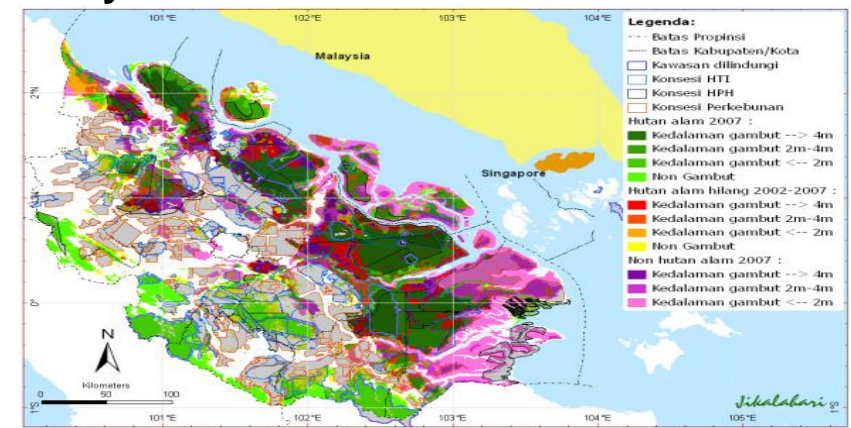

Sumber : Dinas Lingkungan Hidup dan Kehutanan Provinsi Riau

Akibat banyaknya perkebunan monokultur seperti sawit dan sebarannya lahan gambut di provinsi Riau, Banjir dan kekeringan telah memberikan bencana yang tak dapat dihindari oleh provinsi ini, termasuk bencana kabut asap yang rutin menghampiri provinsi Riau rutin menghampiri bencana ekologis tahunan seperti kabut asap. Termudah untuk melihat bahwa tingkat kerusakan lingkungan hidup di Riau sudah sampai pada tahap mengkhawatirkn karena hal ini merupakan suatu indikator. Sampai saat ini pemerintah Riau masih belum memiliki sense of disasters, sehingga bencana yang telah banyak menimbulkan korban jiwa dan kerugian materi ini dianggap bencana biasa saja yang rutin untuk dihadapi dan mitigasinya yang rutin juga dianggarkan untuk setiap tahunnya. Penanganan bencana yang dilakukan pemerintah selama ini hanya terbatas pada proses pemadaman dan sama sekali tidak menyentuh kepada akar masalah, yakni pengelolaan gambut. Asap telah memberikan dampak negative yang cukup besar bagi daerah ini, Bencana ekologis tahunan seperti kabut.

Kebakaran hutan dan lahan merupakan agenda tahunan Riau, khususnya pada musim kemarau (kering). Kerawanan hutan dan lahan di Provinsi Riau terhadap kebakaran sangat terkait dengan kegiatan pembukaan lahan (land 
clearing) dalam usaha pertanian rakyat, usaha perkebunan skala sedang dan besar (perusahaan) serta kegiatan dibidang kehutanan lainnya seperti kegiatan perambahan hutan, okupasi lahan dan pencurian kayu (illegal logging). Bencana kabut asap yang terjadi dalam kurun waktu cenderung lama dan rutin semakin meningkat secara drastis, ini menunjukan bahwa proses penanganan bencana kabut asap tidak dilakukan secara serius. Izin-izin konversi hutan masih saja diterbitkan dalam jumlah besar, bahkan sebagian besar izin konsesi berada pada kawasan lindung gambut, sehingga ketika terjadi praktek land clearing, bencana kebakaran dan kabut asap tak bisa dihindari.

Titik panas yang terdata di Jikalahari terdeteksi sebanyak 86.883 titik api. Berdasarkan Data MODIS, Sepanjang tahun 2001-2008 Dalam span 2001-February 2008, 77\% titik api berada dilahan gambut dengan luasan 387326.5 hektar, 28\% gambut yang terbakar merupakan gambut dalam dan 36\% merupakan gambut sangat dalam dalam dan 36\% (Jikalahari:2008 di dalam Panjaitan, 2015). Penegakan Hukum terhadap kondisi kabut asap yang sudah membahayakan ini ternyata tidak serta merta membuat Perusahaan yang menyebabkan kabut asap berjalan dengan mulus. Yang dilaporkan Bapedal Riau ke Kejaksaan Tinggi Riau tahun 2004 hanya terdiri atas 6 Perusahaan Perkebunan Sawit, 3 Perusahaan HTI dan 1 Perusahaan $\mathrm{HPH}$, hingga kini proses hukumnya tak jelas saja 10 Perusahaan (2 di Bengkalis, 1 Siak, 3 Indragiri Hilir, 2 Rokan Hulu, 1 Pelalawan, 1 Indragiri Hulu) (Jikalahari:2008 di dalam Panjaitan, 2015). Riau telah memberikan dampak yang luas terutama terhadap kondisi ekosistem lingkungan dan makhluk hidup melalui Kebakaran hutan. Menurunnya kualitas udara mengakibatkan meningkatnya penderita penyakit Infeksi Saluran Pernapasan Akut (ISPA) bagi masyarakat terutama bagi anak Balita.

Fenomena tersebutlah yang membuat NGO atau organisasi non-pemerintah tergerakerak untuk menindaklanjuti kasus ini. Perkembangan organisasi non pemerintahan (NGO) didalam panggung politik lingkungan hidup dilihat sebagai bagian dari proses demokratisasi lingkungan hidup (Princen $T$ 1994). Sejak pertemuan Bumi yang diselenggarakan di Rio De Jeneiro pada tahun 1992, partisipasi organisasi masyarakat sipil dalam kebijakan lingkungan hidup mengalami perkembangan yang cepat. Perubahan kebijakan dan tata kelola lingkungan hidup tidak lagi hanya berpusat pada aktor-aktor negara, namun juga peran organizasi masyarakat sipil sebagai perwakilan aktor diluar negara (Guadalope M 2004). Penting dalam diplomasi lingkungan hidup NGO mampu memainkan peran mengenai jaringan advokasi transnasional dalam menanggapi masalah lingkungan hidup hidup (Margaret E 1998) Lingkungan hidup sektor swasta dan mempengaruhi standar keberlanjutan. Dengan kata lain, organisasi non pemerintahan merupakan salah satu aktor yang dominan dalam politik lingkungan hidup kontemporer (Carter 2007).

Organisasi advokasi seperti WALHI baru berdiri pada tahun 1980, sementara WWF di Indonesia masih merupakan kantor perwakilan Kehutanan Departemen WWF Internasional dibawah pengawasan. Kasus karhutla terbesar sepanjang sejarah terjadi pada tahun 1997/1998 yang menghanguskan lahan seluas 11,7 juta hektar dan terjadi secara luas di Kalimantan, Sumatra, Jawa, Bali, Sulawesi dan Nusa Tenggara (Panjaitan 2015). Kabut asap berdampak menimbulkan keluhan kolektif yang luas dalam masyarakat. Kesempatan politik mulai terbuka menjelang kejatuhan pemerintah Orde Baru, Pada masa ini struktur. WALHI secara terbuka melakukan kritik terhadap kebijakan pembukaan lahan gambut sejuta hektar di Kalimantan Tengah 1999 Selatan pada tahun 1999 Serta melakukan investigasi dan 
gugatan terhadap perusahaan pembakar lahan di Sumatera. Pada tingkat local, organisasi non pemerintahan mampu memerankan diri sebagai organisasi gerakan sosial yang mendorong tumbuhnya aksi-aksi kolektif, jaringan lintas kelembagaan dan identitas kolektif sebagai sesama korban kabut asap.

Riau adalah salah satu provinsi di Indonesia dengan persoalan lingkungan hidup yang cukup kompleks. Gambut yang dampaknya tercatat sebagai penyumbang lima terbesar bencana yang terjadi di Indonesia khususnya persoalan laju kerusakan hutan dan ekosistem. Di Riau, Pasca diterbitkannya Inpres 11/2015 tersebut memang kebakaran hutan dan lahan mengalami penurunan signifikan. Namun lahirnya regulasi nasional ini tidak bisa dipandang sebagai faktor tunggal dalam menekan laju kebakaran hutan dan lahan, sebab pada 10 Maret 2016 WALHI Riau bersama CSOs (kelompok masyarakat madani) lainnya melayangkan Gugatan Perbuatan Melawan Hukum dengan menggunakan mekanisme Gugatan Warga Negara (Citizen Lawsuit). Gugatan ini berujung dengan putusan damai yang pada intinya menanggulangi kebakaran hutan dan lahan melalui tindakan-tindakan dan penerbitan kebijakan guna menyelesaikan persoalan asap yang terjadi di Provinsi Riau dan penerbitan kebijakan guna menyelesaikan.

Berangkat dari latar belakang masalah inilah peneliti ingin meneliti "Keterlibatan WALHI Dalam Politik Lingkungan Hidup Terhadap Kasus Kabut Asap Di Riau”, sehingga dapat menemukan temuan baru terkait dengan peran dan strategi yang dilakukan oleh WALHI Riau di dalam proses advokasi kasus kebakaran hutan dan lahan di Riau.

\section{STUDI LITERATUR}

Berakhirnya Perang Dingin mengubah paradigma dalam Hubungan Internasional. Munculnya gerakan transnasional (transnational movement) juga merupakan paradigma baru yang dapat ditemui dalam perkembangan Hubungan Internasional pasca Perang Dingin. Perubahan paradigma ini menandai bahwa ada perkembangan aktor yang signifikan dalam Hubungan Internasional. Negara yang dahulu selalu dielukan sebagai aktor utama di dalam disiplin IImu Hubungan Internasional, tidak lagi mendapat perhatian khusus oleh para akademisi Hubungan Internasional. Akademisi Hubungan Internasional tidak lagi menutup mata dan kaku dalam menerima aktor Hubungan Internasional yang baru. Keberadaan kelompok civil society dan NGOs salah satu contohnya. Kondisi politik internasional yang dinamis dan terbuka pasca Perang Dingin telah membuka jalan untuk aktor sekelas kelompok cilvil society dan NGOs sebagai aktor dalam Hubungan Internasional. Sehingga muncul beberapa isu-isu dalam Hubungan Internasional yang tidak bisa diselesaikan oleh negara namun bisa diselesaikan oleh aktor-aktor transnasional, isu-isu tersebut ialah: HAM, lingkungan, dan hak perempuan.

Keck dan Sikkink merupakan akademisi Hubungan Internasional yang menyajikan pendekatan aktor baru dalam politik internasional. Penggunaan metode komparatif digunakan dalam mengartikulasi dan menganalisis politik internasional. Asumsi ini dibangun atas kondisi politik internasional yang telah berubah mengakibatkan beberapa kebijakan dan tingkah laku aktor juga berubah, termasuk keberadaan kelompok civil society dan NGOs yang dimasukkan ke dalam variabel yang bisa mengubah normative power dengan efektivitas dan kebangkitan jaringan yang dimiliki oleh kelompok civil society dan NGOs tersebut. Sebelum menggunakan teori dari Keck dan Sikkink, pemahaman tentang kekuatan yang dimilik oleh NGO 
atau CSO banyak berpengaruh dalam mengonstruksi suatu isu hingga memancing isu tersebut menjadi masalah transnasional.

Tulisan Tarrow (Tarrow 1994) misalnya yang menyebutkan bahwa kekuatan pergerakan sosial (social movement) merupakan gerakan yang memiliki nilai aksi bersama (contentious collective action) yang bisa dibawa melalui medium institusional. Untuk menghubungkan gerakan sosial dan aspek politik bisa dilihat dari konsep "kesempatan politik" (political opportunity) dari (Meyer, David S 2004) dan (Giugni 2009) yang menggambarkan bahwa gerakan sosial dapat memiliki kekuasaan dalam bentuk politik, salah satunya pada penegakan hak-hak sipil di Amerika Serikat dan untuk isu lingkungan. Untuk membawa isu tersebut menjadi kajian Hubungan Internasional dapat dilihat dari struktur domestik dari gerakan sosial yang dibawa oleh NGO dan CSO tersebut. Hal ini dikarenakan struktur domestik memengaruhi struktur kesempatan politik yang dimiliki oleh NGO dan CSO tersebut, baik ditingkat supra-nasional, transnasional, dan nasional. Menggabungkan isu domestik yang memiliki isu transnasional memiliki cara yang unik untuk diselesaikan karena harus melihat model interakis antara aktor domestik dengan aktor transnasional, Robert Putnam di dalam (Tarrow, Sidney, Della Porta 2018) telah menjelaskan bahwa isu domestik dapat diselesaikan melalui diplomasi model dua tingkat (two-level game model) yang memiliki interaksi yang ajeg dan dinamis untuk ditelaah.

Untuk menyederhanakan relasi kekuasaan dan strategi dalam kelompok gerakan sosial atau NGO/CSO, Keck dan Sikkink telah menyederhanakan suatu teori yakni "advokasi transnasional" (transnational advocacy) yang telah membagikan beberapa tipologi untuk melihat relasi kuasa dan politik pada gerakasan sosial, NGO, dan CSO dalam menanggapi suatu isu Hubungan Internasional.

Terdapat empat tipologi yang dilakukan oleh kelompok advokasi transnasional (transnational advocacy) dalam rangka sosialisasi (Margaret E 1998), antara lain: (1) information politics, yaitu kemampuan dalam menghasilkan informasi dan mengarahkan dampak yang akan terjadi dari informasi yang didapat, (2) symbolic politics, yakni kemampuan dalam menyerukan simbol maupun aksi yang dapat memunculkan opini publik dan framing serta konstruksi suatu isu, (3) leverage politics, merupakan kemampuan dalam memengaruhi situasi tertentu pada saat salah satu pihak tidak mampu memberikan pengaruh, dan (4) accountability politics, adalah usaha dalam mempertahankan aktor yang berkuasa agar tetap memegang kebijakan yang telah ditetapkan.

Sumber penelitian terdahulu pertama yang diambil oleh peneliti dalam masalah penelitian ini ialah tulisan dari Susan Park yang berjudul The Role of Transnational Advocacy Networks in Reconstituting International Organization Identities yang diterbitkan oleh Journal of Diplomacy and International Relations pada tahun 2004. Susan Park memulai tulisan nya dengan analogi aktor transnasional yang bisa menggantikan negara sebagai aktor utama dalam Hubungan Internasional. Peristiwa-peristiwa yang terjadi pasca Perang Dingin banyak memberikan kontribusi untuk NGO (non-governmental organizations) dan IO (International Organization) menggeser peran negara sebagai aktor utama, karena ada perkembangan isu Hubungan Internasional yang tidak bisa lagi dan efektif dikelola oleh negara seperti isu lingkungan, pembangunan, HAM, dan keilmuwan. Sifat agensi yang dimiliki oleh aktor transnasional akan semakin memiliki legitimasi apabila aktor transnasional seperti NGO dan 10 bisa meraih pencapaian yang seharusnya dilakukan oleh negara. Namun tidak jarang juga, beberapa NGO dan IO 
beroperasi sesuai dengan pengaruh kemampuan, pemahaman yang dimilik, dan kepentingan suatu negara seperti yang diungkapkan oleh Kenneth Abbott dan Duncan Snidal dalam tulisan ini (Park 2004).

Peran norma internasional juga disebut oleh Susan Park sebagai indikator yang memengaruhi batasan dan sifat agensi suatu NGO untuk bergerak. Ide-ide kolektif bisa saja dimunculkan namun tingkat ke subjektivan terhadap isu juga berpengaruh, sehingga inter-subjektivitas NGOs dalam melihat isu dalam menyamakan nilai cenderung berpengaruh (Park 2004). Susan Park juga menjelaskan hal dasar (basic rule of the game) dalam melihat tingkah laku NGOs, yakni kolektivitas norma dan konstruksi identitas sosial akan membuat NGOs sebagai aktor menemukan pola interkasi mereka (Park 2004). Jurnal ini memberikan pemahaman bagi peneliti untuk menelaah pola tingkah laku WALHI dalam keterlibatannya dengan kegiatan advokasi transnasional terkait kasus kabut asap di Riau.

Tulisan kedua yang dikutip oleh peneliti dalam penelitian ini ialah tulisan dari Joe Stillerman yang berjudul Transnational Activist Networks and The Emergence of Labor Internationalismin The NAFTA Countries (Stillerman 2003). Stillerman dalam tulisannya banyak menganalogikan gerakan advokasi transnasional sebagai gerakan buruh yang bersinggungan langsung dengan proses perubahan politik (political opportunities) (Stillerman 2003). Beberapa negara di Eropa pasca Perang Dingin banyak menghadapi kemunculan organisasi-organisasi yang bersifat kompleks, salah satunya ialah gelompok advokasi internasional, sehingga menyebabkan kelompok advokasi transnasional dapat berpolitik bahkan menyebarkan ideologi dan nilai mereka ke penjuru negara lain. Kesamaan tulisan Stillerman ini dengan tulisan Susan Park ialah memiliki argumen yang sama dalam melihat aktivitas gerakan advokasi transnasional, yakni dengan memanfaatkan kebangkitan arena politik advokasi transnasional yang memanfaatkan aliansi lintas batas negara (cross-national alliances) untuk memengaruhi kebijakan dalam negara asal kelompok advokasi transnasional tersebut yang merujuk pada proses politik pergerakan nasional dari negara asal kelompok advokasi tersebut (Stillerman 2003). Kerangka kerja kelompok pergerakan nasional memiliki variabel dependen seperti; cikal bakal keberadaan jaringan organisasi, sumberdaya, organisasi, dan proses politik yang meliputi; pembagian kelompok, kelompok sekutu, tingkat rendah kemampuan kelompok pesaing, dan kemampuan kelompok untuk mengkonstruksi nilai dengan kolektfitas identitas (Stillerman 2003). Pola ini sangat cocok untuk menelaah gerakan advokasi transnasional yang bergerak di bidang lingkungan dan ekonomi. WALHI termasuk kelompok organisasi advokasi internasional yang banyak terpengaruh oleh pola-pola gerakan tersebut, sehingga tulisan ini banyak memberikan pemahaman dari segi rujukan bagi peneliti.

Perspektif baru ditawarkan oleh Sidney Tarrow dalam melihat akitivitas NGOs pasca Perang Dingin, hal ini dapat dilihat dari tulisan nya yang berjudul " $A$ landmark in scholarly activism beyond borders: a review of Keck and Sikkink's Transnational advocacy networks in international and regional politics" tahun 2019 (Tarrow 2019). Tulisan ini merupakan ulasan dari Tarrow terhadap teori Keck dan Sikkink yang akan peneliti gunakan dalam penelitian ini. Tarrow memulai ulasan nya dengan memaparkan bahwa untuk memahami teori advokasi transnasional ada tiga hal utama yang perlu diperhatikan oleh akademisi (Tarrow 2019), yakni: pertama, teori ini merupakan teori yang dikembangkan secara capaian inter-disipliner (interdiciplinary reach), yang menggabungkan antara perbandingan politik dan Hubungan Internasional. Keck dan Sikkink dalam pandangan Tarrow melihat ada upaya 
penggabungan kepentingan politik bagi kelompok NGOs dan CSOs namun dibatasi oleh garis demarkasi antara urusan domestik dan politik internasional, oleh karena itu konsep "networks" ditekankan dalam penggunaan teori ini. Kedua, yakni adanya upaya penggabungan Hubungan Internasional dengan Sosiologi dengan mengambil istilah konstruksi sosial dari dalam atau disebut intra-diciplinary ecumenism.

Di dalam $\mathrm{HI}$ istilah ini mirip dengan teori-teori yang ditawarkan oleh perspektif konstruktivisme. Ketiga, yakni mekanisme dan proses konstruksi isu transnasional atau dikenal dengan isitilah "pola bumerang". Pada tahapan ini aktivis transnasional akan menolak untuk mengetahui segala klaim pembelaan negara terhadap masasalah yang ada di dalam domestik (tempat dimana aktivis itu berada) untuk memengaruhi perilaku negara sehingga pada ada interaksi antara negara dengan kelompok aktivis domestik itu akan memancing kelompok aktivis dari luar negara tersebut untuk memberikan tekanan, hal ini lah yang disebut dengan "pola bumerang" melemparkan masalah yang ada ke negara hingga sampai ke luar negeri, dan kelompok aktivis internasional datang dari luar negeri untuk menekan masalah domestik suatu negara tersebut, mirip dengan bumerang yang dilemparkan. Di dalam pola ini diperlihatkan bagaimana interaksi yang berbasiskan variabel ontologi antara negara, transnasional NGOs atau CSOs, dan kelompok aktivis domestik, hal inilah yang disebut oleh Keck dan Sikkink sebagai proses "politik advokasi transnasional", namun Tarrow lebih memilih menggunakan kata "mekanisme" untuk menjelaskan fenomena tersebut (Tarrow 2019).

Penelitian terdahulu yang diambil oleh peneliti berikutnya diambil dari tulisan Lisa Jordan yang berjudul Political Responsibility in Transnastional NGO Advocacy (Jordan 2000). Jordan memulai tulisan nya dengan pemaparan telaah aktivitas NGO yang merupakan suatu fenomena baru dalam Hubungan Internasional. Cakupan aktivitas NGO mulai dari arena internasional, nasional, dan lokal. Dimensi yang ditekankan oleh Jordan yang dinilai sangat menarik yang dikutip dari tulisan Keck dan Sikkink ialah tentang jaringan advokasi "network advocacy", Jordan lebih melihat konsep ini memiliki makna sebagai aktivitas manajemen resiko dan tensi dalam advokasi internasional. Setiap NGO yang memiliki jaringan advokasi dinilai oleh Jordan memiliki standar manajemen resiko dan tensi yang sama dalam menjalankan fungsinya (Jordan 2000). Selain itu ada hal yang menarik yang ditelaah oleh Jordan selain kemampuan NGO yang tadi, yakni efektivitas NGO dalam mengampanyekan objek permasalahan yang ada yakni tanggungjawab politik (political responsibility) yang harus muncul sebelum dan sesudah masa kampanye, ketika NGO tidak melakukan itu maka NGO telah membawa organisasi ke dalam jurang kritik legitimasi dan akuntabilitas dihadapan masyarakat, seperti yang dikemukakan oleh Nelson (1997) dalam (Jordan 2000).

Tanggungjawab politik (political responsibility) menurut Jordan ialah komitmen untuk meraih tidak hanya tujuan tetapi juga bagian dari prinsip demokrasi yang harus ditegakkan oleh NGO di dalam proses jejaringan dan kampanye nya. Tanggungjawan politik (political responsibility) konsep normatif dari akuntabilitas yang ada di dalam obligasi formal dalam definisi demokrasi. Sehingga dalam konteks praktik, NGO dapat direlasikan dengan kekuasaan dan tanggungjawab dalam proses transnasional advokasi (Jordan 2000). Ada beberapa indikator yang termasuk di dalam tanggungjawab politik (political responsibility) yang dikemukakan oleh Jordan, yakni: pembagian arena-arena politik (dividing political arenas), agenda pengaturan dan pembangunan strategi (agenda setting and strategy building), penggalangan dan alokasi sumber dana (raising and allocating financial resources), arus informasi (information flow), bentuk keteraturan infornasi (information frequency 
and format), penerjemahan informasi ke dalam beberapa bentuk penggunaan (information translation into useful forms), peresmian hubungan (the formalization of relationship) (Jordan 2000). Tulisan Jordan ini banyak memberikan pemahaman baru bagi peneliti untuk melihat lebih dalam bagaimana keberadaan NGO dalam hal tanggungjawab politik dalam jaringan advokasi transnasional.

Sumber penelitian terdahulu terakhir yang diambil oleh peneliti ialah tulisan dari David Ardhian, Adiwibowo, dan Wahyuni yang berjudul Peran dan Strategi Organisasi Non Pemerintahan Dalam Arena Politik Lingkungan Hidup (Ardhian, Adiwibowo, and Wahyuni 2016). Tulisan ini diambil oleh peneliti karena banyak memberikan informasi tentang keterkaitan permasalahan kebakaran hutan dan lahan (karhutla) dengan organisasi non-pemerintahan (NGO) secara umum. Tulisan ini juga mengulas proses kontruksi isu oleh NGO terkait karthutla dan menggunakan analisa advokasi transnasional dimulai dari adanya ketimpangan kuasa dalam kasus karhutla yang terjadi di Indonesia sehingga menjadi sumber informasi bagi peneliti untuk meneliti hal yang sama dengan lingkup lebih khusus.

\section{METODE PENELITIAN}

Penelitian ini termasuk jenis penelitian kualitatif, yaitu penelitian yang bertujuan untuk memahami fenomena tentang apa yang dialami oleh subjek penelitian, yang terkaitan dengan perilaku, persepsi, motivasi, tindakan dan aspek lain secara intrepetatif dan holistik. Metode penelitian yang digunakan adalah deskriptif analitik, yaitu penelitian yang bertujuan untuk memberikan deskripsi tentang realitas pada objek yang diteliti secara objektif dan komprehensif. Deskriptif karena menggambarkan secara spesifik suatu situasi, social-setting, ataupun suatu hubungan, dan analitis karena menjelaskan keterkaitan antara variabel independen dan variable dependen (Neuman, 2000). Penelitian ini menggunakan teknik pengolahan data kualitatif interpretatif. J.W Creswell menerangkan bahwa interpretasi data dilakukan dengan cara mengartikan, menterjemahkan dan membuat data tersebut menjadi lebih mudah untuk dipahami melalui sudut pandang masyarakat yang diteliti (J.W. Creswell, 2009).

Teknik pengumpulan data yang dilakukan dalam penelitian ini adalah studi pustaka. Pada umumnya, teknik pengumpulan data yang digunakan dalam metode kualitatif cukup beragam, diantaranya observasi, wawancara, studi pustaka, wawancara mendalam (in-depth interview) dan materi audio-visual.

\section{PEMBAHASAN}

\section{Korelasi Bencana Kabut Asap di Riau dengan WALHI Riau}

Kabut asap lintas batas di Asia Tenggara khususnya di Indonesia, tepatnya di provinsi Riau adalah contoh utama dari krisis lingkungan internasional. Khususnya persoalan laju kerusakan hutan dan ekosistem gambut yang dampaknya tercatat sebagai penyumbang lima terbesar bencana yang terjadi di Indonesia Riau merupakan salah satu provinsi di Indonesia dengan persoalan lingkungan hidup yang cukup kompleks. (Fandi 2020). Di Riau, pasca diterbitkannya Inpres 11/2015 tersebut memang kebakaran hutan dan lahan mengalami penurunan signifikan. Namun lahirnya regulasi nasional ini tidak bisa dipandang sebagai faktor tunggal dalam menekan laju kebakaran hutan dan lahan, sebab pada 10 Maret 2016 WALHI Riau bersama CSOs (kelompok masyarakat madani) lainnya melayangkan Gugatan Perbuatan Melawan Hukum dengan menggunakan mekanisme Gugatan Warga 
Negara (Citizen Lawsuit). Gugatan ini berujung dengan putusan damai yang pada intinya, negara berkomitmen bersama-sama menanggulangi kebakaran hutan dan lahan melalui tindakan-tindakan dan penerbitan kebijakan guna menyelesaikan persoalan asap yang terjadi di Provinsi Riau dan penerbitan kebijakan guna menyelesaikan persoalan (Fandi 2020).

Dampak negatif kebakaran hutan dan lahan meliputi sektor ekonomi, pariwisata, transportasi, pertanian, kesehatan dan kepuasan hidup penduduk di sebagian besar di wilayah Indonesia khususnya di provinsi Riau, Kehadiran Kelompok Masyarakat Madani (civil society grup) atau NGO (Non-Governmental Organizations) menambah dinamika dalam proses advokasi isu tersebut hingga isu tersebut dibawa dalam ranah pencegahan hingga penyelesaiannya. Proses advokasi dari tahapan lokal hingga internasional yang dilakukan oleh civil society grups atau NGO yang merupakan bagian dari konsep kesempatan politik (political opportunity) dalam beberapa penelitian terdahulu dianggap mampu hadir sebagai penengah dalam penyelesaian isu kabut asap ini.

Pada tahun 2019 bencana asap kembali terjadi, khususnya di wilayah Riau dilansir dari CNN Indonesia, Januari hingga Juli 20194.258 titik api di seluruh Indonesia, 1.030 titik api berasal dari Riau sendiri, keberadaan NGO (Non Govermental Organization) sebagai komoditi masyarakat sipil (Civil Society) tidak terlepas daripada kondisi dari politik/institusi masyarakat (political society), hadir karena institusi politik tersebut semakin berkurang efektifitasnya dan semakin kuatnya hegemoni negara, dan juga marginalsasi sebagai dampak buruk dari pembangunan (Cholisin 2015).

Masa sekarang NGO bermunculan dari persoalan lingkungan hidup dan politik ekologi, fokus-fokus gerakan mereka terletak pada isu developmentalisme, yakni memperjuangkan dan mempromosikan keadilan bagi kelompok rentan atas sumber daya lingkungan (Bryant and Bailey 1997). Kekhawatiran manusia terhadap lingkungan hidup mereka juga menjadi awal dari munculnya NGO yang mempunyai kekhawatiran terhadap degradasi lingkungan yang terjadi akibat aktivitas ekonomi setelah perang dunia kedua (Ikbar 2014). Dalam khasanah teori gerakan sosial, gerakan lingkungan hidup merupakan bagian dari Gerakan Sosial Baru (GSB). Gerakan sosial lama memfokuskan pada foundation content dan terkait dengan kepentingan kelas atau kelompok sosial tertentu seperti gerakan buruh dan gerakan petani, sementara gerakan sosial baru lebih menekankan pada masalah ide dan nilai serta melibatkan aktor yang lebih plural seperti gerakan feminisme, gerakan hak asasi manusia, gerakan hak asasi manusia termasuk gerakan lingkungan hidup hidup (Fauzi and Herlily 2005).

Wahana Lingkungan Hidup Indonesia (WALHI) merupakan salah satu NGO yang bergerak di bidang lingkungan, tujuan utama WALHI adalah mengawasi pembangunan yang berjalan saat ini dengan mempromosikan solusi untuk menciptakan lingkungan yang berkelanjutan serta menjunjung tinggi keadilan social masyarakat. Terkhususnya di Riau, WALHI memberikan perhatian kepada kasus bencana asap yang terjadi hampir setiap tahun terjadi di Riau. WALHI juga tidak terlepas peran mereka sebagai NGO berbentuk advokasi transnasional (Transnational Advocacy) dalam menanggapi kasus bencana asap. WALHI Riau melihat fenomena kebakaran hutan dan lahan yang terjadi berulang kali disebabkan oleh tata kelola pemerintah terhadap lingkungan yang buruk. Dalam pengendalian kebakaran hutan dan lahan sangat diperlukan instansi pemerintah baik di tingkat provinsi maupun kabupaten/kota dan juga diperlukan partisipasi dari masyarakat. 
Ada lima instansi pemerintah yang berperan dalam pengendalian kebakaran hutan dan lahan sebagai berikut:

1. Dinas Kehutanan, berperan sebagai koordinator dalam menyusun regulasi atau kebijakan pencegahan atau pengendalian kebakaran hutan dan lahan.

2. Badan Penanggulanggan Bencana Daerah (BPBD), berperan sebagai koodinator pengendalian dan pencegahan kebakaran hutan dan lahan.

3. Badan Lingkungan Hidup (BLH), berperan untuk mengendalikan dampak lingkungan yang disebabkan oleh kebakaran hutan dan lahan seperti air, udara dan tanah.

4. Badan Pengendalian Dampak Lingkungan (Bappedal), yang berperan sebagai penanggulangan kerusakan atau pencemaran lingkungan yang disebabkan oleh kebakaran lahan dan hutan.

5. Dinas Perkebunanan (Disbun), berperan sesuai dengan tugas pokok sebagai pusdalkarhutla yang mempunyai tanggung jawab.

WALHI berperan sebagai aktor yang melakukan aktivitas transnational advocacy. Aktivitas dari aktor ini sangat unik karena pada umumnya aktor ini terorganisasi dalam mempromosikan suatu perkara, ide-ide, norma-norma juga turut serta melibatkan individu untuk turut serta dalam mengadvokasi perubahan kebijakan. Aktor ini tidak mengandalkan fisik dalam konsep transnational advocacy melainkan caranya lebih ke dalam jaringan-jaringan yang mereka miliki dan biasanya aktor memiliki pengaruh, sehingga membuat pergerakan mereka dapat diperhitungkan. Seperti yang ditegaskan oleh Fandi Deputi WALHI Riau "WALHI Riau menjadi pelopor perubahan kebijakan dan cara pandang dalam pengelolaan lingkungan salah satunya kebakaran hutan dan lahan. Kebakaran yang terjadi bukanlah semata-mata diakibatkan oleh alam tetapi jauh sebelum itu disebabkan oleh alih fungsi hutan sehingga mengubah data tampung dan daya dukung lingkungan. WALHI Riau terus memberikan tekanan kepada pemerintah selaku pemberi izin dan swasta selalu peminta dan penerima izin" (Fandi 2020).

Sebagai LSM atau civil society grup (kelompok masyarakat madani), pengaruh WALHI Riau dalam mengadvokasi permasalahan kebakaran hutan dan lahan sudah sampai ke tahap nasional dan internasional dari tekanan yang dilakukan melibatkan jaringan WALHI Eksekutif Nasional dan jaringan Friend Of the Earth Internasional dimana WALHI salah satu anggotanya. seperti (E Keck and Sikkink 1998) dalam tulisannya yang berjudul "Transnational advocacy networks in international and regional politics", memiliki normative power (kekuatan normatif) dalam mengubah kebijakan dan tingkah laku aktor lain (stakeholder) yang terlibat dalam suatu permasalahan. Untuk mencapai tujuan WALHI melakukan advokasi yang meliputi: penyelamatan lingkungan hidup, pengorganisasian rakyat, pendidikan kritis, kampanye dan riset, litigasi, menggalang aliansi kekuatan masyarakat sipil, menggalang dukungan publik.

Dalam hal ini secara organisasi WALHI Riau memiliki tujuan mendorong terwujudnya pengakuan hak asasi manusia sebagai bentuk dari tanggung jawab negara atas pemenuhan sumber sumber kehidupan rakyat. Sejalan dengan itu WALHI Riau telah memiliki kemampaun untuk mambangun jaringan (networks) baik sifatnya nasional maupun transnasional. Jaringan yang sifatnya Nasional WALHI Eksekutif Daerah Riau hanya satu dari 28 Eksekutif Daerah yang berpusat di WALHI Nasional, kerja penyelamatan lingkungan akan sangat efektif jika melibakan banyak orang bukan hanya NGO tapi juga publik. Terkait advokasi melawan asap WALHI Riau bekerja sama dengan jaringan lokal LBH-YLBHI Pekanbaru, Eyes On the 
Forest (EOF), Rumah Budaya Siku Keluang, Jikalahari, seluruh lembaga anggota WALHI Riau dan banyak komunitas, organisasi mahasiswa, MAPALA, dan organisasi terkait lainnya (Fandi, 2020).

Untuk jaringan yang bersifat transnasional WALHI merupakan anggota dari Friend of the Earth (FoE) yang terdiri dari 73 kelompok anggota nasional dan sekitar 5.000 kelompok aktivis lokal di setiap benua. Dengan lebih dari 2 juta anggota dan pendukung di seluruh dunia, berkampanye tentang masalah lingkungan dan sosial yang paling mendesak saat ini. Kerja sama level nasional ada WALHI nasional, ICEL, dan YLBHI (Fandi, 2020). Kampanye ini juga didukung oleh FoE, pada saat ketika terjadi kebakaran dan kerusakan lingkungan seluruh anggota melakukan kampanye dengan cara masing-masing di negaranya. WALHI menantang model globalisasi ekonomi dan korporasi saat ini, dan mempromosikan solusi yang akan membantu menciptakan masyarakat yang berkelanjutan secara lingkungan dan sosial.

WALHI juga melakukan aktivitas pengumpulan informasi dalam kasus kebakaran hutan dan lahan di Riau dengan cara melakukan pemantauan terhadap hotspot yang terjadi di provinsi Riau serta meneruskan kepada publik melalui media sosial. dan memainkan kemampuan untuk menggunakan simbol-simbol atau juga tindakan-tindakan maupun sebuah cerita untuk menggambarkan bencana asap yang terjadi di Riau, seperti kampanye melalui media sosial WALHI Riau.

Melalui simbol-simbol tersebut WALHI sebagai aktor menggambarkan bagaimana bencana asap akibat dari kebakaran hutan membahayakan bagi warga korban bencana asap di Riau, selain itu tindakan-tindakan WALHI Riau juga seperti demo damai yang dilakukan mereka di Pekanbaru, juga aksi demo mereka di Jakarta Pusat yang mengajak semua masyarakat lokal dan internasional untuk ikut serta dalam aksi damai mereka, WALHI Riau terus melakukan pelaporan kasus terhadap perusahaan pelaku pembakar lahan. Melakukan gugatan hukum terhadap kelalaian pemerintah dalam mengatasi kebakaran utan dan lahan.

WALHI Riau memiliki pengaruh di dalam permasalahan kebakaran hutan dan lahan di provinsi Riau ditunjukkan dari gugatan citizen lawsuit yang WALHI Riau lakukan kepada pemerintah merubah cara pemerintah dalam memangani kejadian kebakaran dan bagaimana bersiap menghadapi persoalan kebakaran hutan dan lahan atau yang terkait dengan kesenjangan lingkungan. 


\section{Gambar 2. Akta Perdamaian WALHI Riau dengan Pemerintah}

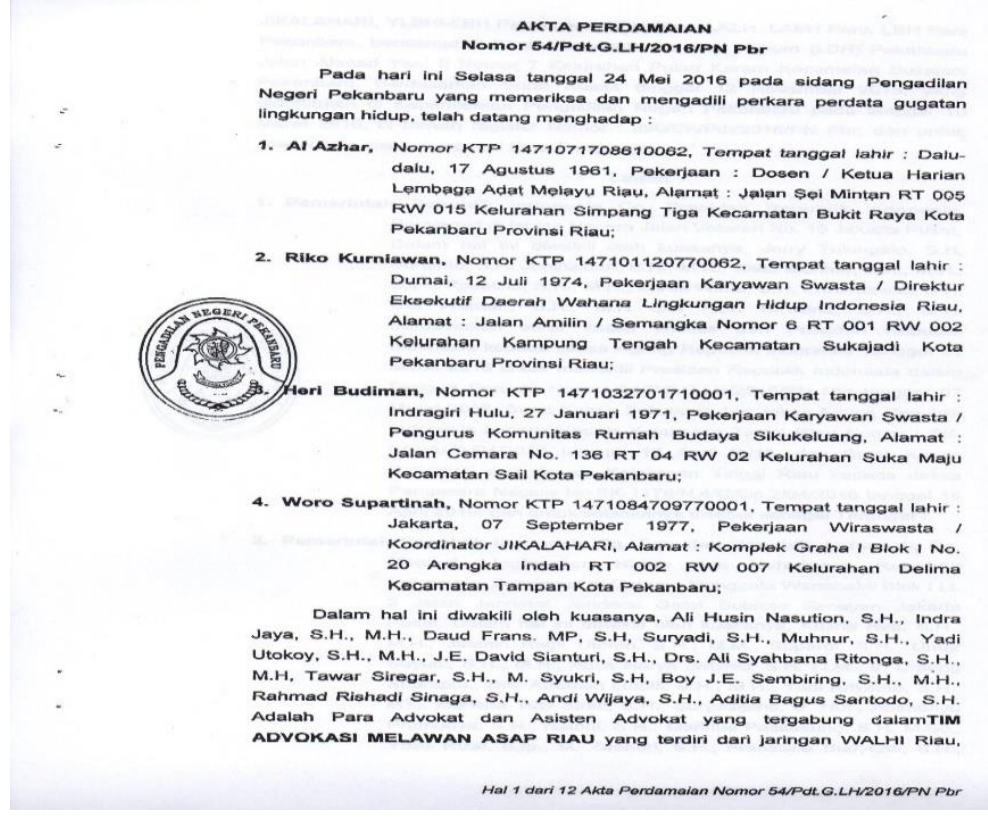

Sumber: Fandi 2020

Negara menjamin hak setiap orang untuk hidup layak, menghirup udara yang sehat/bersih. Riau adalah bumi kita, lingkungan kita, dampak yang ditimbulkan dari kejadian pembakaran merupakan tanggung jawab kita. Bagaimana proses perizinan yang diberikan sudah sesuai dengan peraturan yang berlaku. Bagaimana proses menjalankan bisnis harus diawasi. Bagaimana hak masyarakat asli dan masyarakat adat yang hak atas wilayah kelolanya direbut oleh izin harus mendapatkan perhatian. Banyak hal tersebut tidak dilakukan secara transparan dan berkeasilan. WALHI Riau hanya menjalankan mandat atas dukungan masyarakat (Fandi 2020:Deputi Direktur WALHI Riau)

\section{Peran WALHI sebagai CSOs dalam Politik Lingkungan Hidup}

Kebakaran hutan seringkali menjadi ancaman bagi lingkungan Indonesia, pada musim kemarau apalagi musim kering ekstrim kebakaran hutan dan lahan terjadi di banyak tempat. Seolah sudah menjadi musim ketiga bagi Indonesia selain musim hujan dan kemarau, bukan hanya kebakaran lahan akan tetapi hutan lindung juga ikut terbakar. Penyebabnya bisa dikarenakan alam, tetapi peran paling besar disebabkan oleh manusia demi meraih keuntungan sendiri atau masing-masing kelompok.

Efek dari kebakaran ini adalah asap yang menyengsarakan masyarakat lokal yang terkena bencana asap, hingga negara-negara tetangga seperti Singapura, Malaysia, Brunei terkena asap akibat dari kebakaran hutan, lebih dari itu timbul masalah kesehatan yang oleh bencana asap ini berupa Infeksi Saluran Pernapasan Akut (ISPA) yang mengakibatkan ribuan orang terkena ISPA, anakanak yang seharusnya pergi sekolah terpaksa diliburkan akibat dari asap yang berasal dari kebakaran hutan tersebut.

Sektor riil dari perekonomian juga terkena imbas dari bencana asap tersebut, Bank Indonesia menyatakan bahwa dampak tersebut dirasakan langsung oleh angkutan udara yang tidak bisa melakukan penerbangan atau mendarat di kota 
tujuan karena terhalang asap yang sangat tebal, pengiriman kargo juga tertimbun akibat barang tidak bisa sampai ketujuan. Efek bencana asap ini juga berdampak terhadap ekonomi masyarakat, penurunan pendapatan akibat dari biaya kesehatan yang ditimbulkan oleh asap. Hal ini terjadi dalam satu periode waktu tertentu (musim kemarau) namun intensitas dari pengulangan dampak asap tersebut bisa terjadi setiap tahun.

Laporan Bank Dunia yang diterbitkan pada Fire Milik Cost 2016, tercatat sepanjang 2015 Indonesia mengalami kebakaran lahan seluas 2,6 juta hektare. Pada tahun 2019 bencana asap merajarela, khususnya di wilayah Riau dilansir dari CNN Indonesia, Januari hingga Juli 20194.258 titik api di seluruh Indonesia, 1.030 titik api berasal dari Riau sendiri, keberadaan NGO (Non Govermental Organization) sebagai komoditi masyarakat sipil (Civil Society) tidak terlepas daripada kondisi dari politik/institusi masyarakat (political society), dimana institusi politik tersebut semakin berkurang efektifitasnya dan semakin kuatnya hegemoni negara, dan juga marginalsasi sebagai dampak buruk dari pembangunan. (Cholisin 2015)

Masa sekarang NGO bermunculan dari persoalan lingkungan hidup dan politik ekologi, yang dimana fokus-fokus gerakan mereka terletak pada isu developmentalisme, yakni memperjuangkan dan mempromosikan keadilan bagi kelompok rentan atas sumber daya lingkungan (Bryant and Bailey 1997). Kekhawatiran manusia terhadap lingkungan hidup mereka juga menjadi awal dari munculnya NGO yang mempunyai kekhawatiran terhadap degradasi lingkungan yang terjadi akibat aktivitas ekonomi setelah perang dunia kedua (lkbar 2014). Dalam khasanah teori gerakan sosial, gerakan lingkungan hidup merupakan bagian dari Gerakan Sosial Baru (GSB). Gerakan sosial lama memfokuskan pada foundation content dan terkait dengan kepentingan kelas atau kelompok sosial tertentu seperti gerakan buruh dan gerakan petani, sementara gerakan sosial baru lebih menekankan pada masalah ide dan nilai serta melibatkan aktor yang lebih plural seperti gerakan feminisme, gerakan hak asasi manusia, gerakan hak asasi manusia termasuk gerakan lingkungan hidup hidup dan gerakan lingkungan (Fauzi and Herlily 2005).

Tidak sesuainya relasi antara dalam kasus kebakaran hutan bisa dilacak dari sejarah panjang pembukaan hutan, termasuk hutan lindung, gambut, rawa berdasarkan kepentingan ekonomi. Meningkatnya kejadian karhutla dari tahun ketahun juga sangat berhubungan dengan ekspansi industri berbasis hutan dan lahan, seperti ekspansi industri kayu sejak tahun 1970-an dan perluasan perkebunan kelapa sawit yang berlangsung sejak tahun 1990-an (Purnomo et al. 2015).

WALHI (Wahana Lingkungan Hidup Indonesia) merupakan salah satu NGO yang bergerak di bidang lingkungan, tujuan utama WALHI adalah mengawasi pembangunan yang berjalan saat ini dengan mempromosikan solusi untuk menciptakan lingkungan yang berkelanjutan serta menjunjung tinggi keadilan sosial masyarakat. Terkhususnya di Riau, WALHI memberikan perhatian kepada kasus bencana asap yang terjadi hampir setiap tahun terjadi di Riau, WALHI juga tidak terlepas peran mereka sebagai NGO berbentuk advokasi transnasional (Transnational Advocacy) dalam menanggapi kasus bencana asap.

WALHI berperan sebagai aktor dari transnational advocacy, bahwa cara dari aktor ini sangat unik karena pada umumnya aktor ini terorganisasi dalam mempromosikan suatu perkara, ide-ide, norma-norma juga turut serta melibatkan individu untuk turut serta dalam mengadvokasi perubahan kebijakan. Aktor ini tidak mengandalkan fisik dalam konsep transnational advocacy melainkan caranya lebih 
ke dalam jaringan-jaringan yang mereka miliki dan biasanya aktor memiliki pengaruh, sehingga membuat pergerakan mereka dapat diperhitungkan.

Keck dan Sikkink berpendapat, bahwa ada strategi yang biasa digunakan aktor-aktor ini dalam transnational advocacy. Ada empat macam strategi tersebut yaitu Information Politics, Symbolic Politics, Leverage Politics, dan Accountablity Politics. Berdasarkan strategi tersebut, peneliti akan menguraikan strategi yang digunakan WALHI dalam bencana kabut asap yang terjadi di Riau sesuai dengan kriteria yang disebutkan sebelumnya.

\section{Politik Informasi (Information Politics)}

WALHI dalam mempengaruhi keterlibatan mereka memakai cara politik informasi, cara ini digunakan WALHI dalam memobilisasi masyarakat untuk proaktif terhadap bencana asap, baik masyarakat lokal maupun internasional, cara ini bisa kita lihat melalui media masa cetak maupun media daring, selain itu mereka juga melakukan information politic melalui situs WALHI, seperti contoh gambar berikut:

Gambar 3. Data Penderita ISPA di Riau

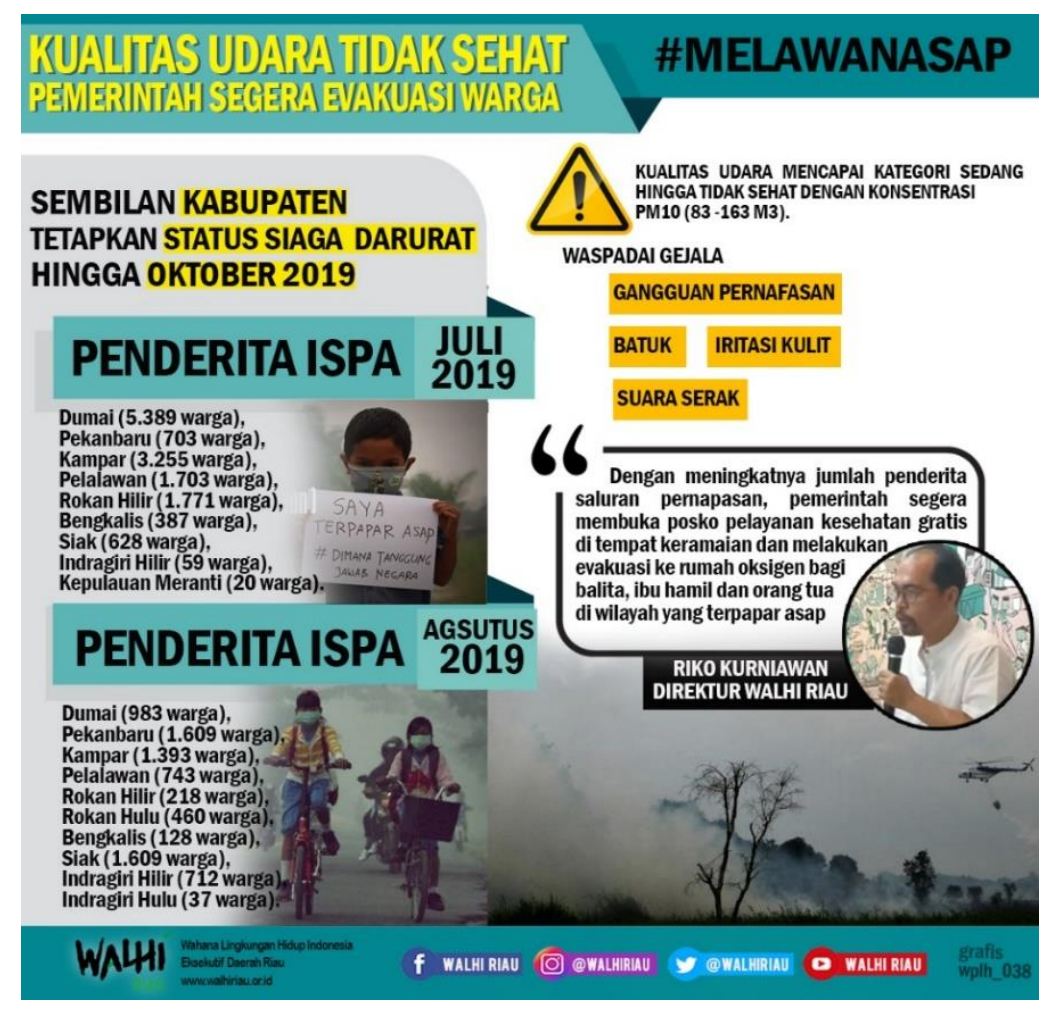

Sumber : Website WALHI Riau 2019

Melalui media daring, WALHI melakukan information politic sebagai contoh berita yang dimuat dalam media daring tempo yang menceritakan, akibat bencana asap yang diakibatkan pembabatan hutan tanpa memperhatikan berkelanjutan membuat mantan direktur WALHI Jhony Setiawan Mundung yang harus memakai tabung oksigen bergantian dengan istri dan anak-anaknya dimana asap hingga masuk ke dalam rumah pada saat itu dan membuat keluarganya tidak bisa tidur dengan nyaman (Persada 2019). 
Masyarakat internasional juga menjadi target dari Information Politic yang dilakukan oleh WALHI, pemberitaan tentang gerakan aktor tersebut secara internasional diliput oleh The Jakarta Post, pemberitaan dalam media tersebut berisi tentang WALHI dan NGO lainnya menuntut Presiden, Menteri KLHK, Menteri Kesehatan dan Kementrian Agraria dan Tata Ruang juga turut serta Pemerintah Provinsi Riau gagal dalam melindungi masyarakat Riau dari bencana asap (Harahap 2016).

Aksi WALHI ini mirip seperti yang dijabarkan oleh King yang menyamakan tindakan WALHI dengan gerakan lain yakni gerakan yang melindungi warga Chiapas, Meksiko, bagaimana sarana media masa maupun cetak dan elektronik untuk membetuk jaringan advokasi dan menggerakkan masyarakat (King 2004).

WALHI memakai information politic dengan baik, sehingga tindakan mereka mencakup perhatian masyarakat lokal dan internasional melalui media lokal, internasional atau situs yang mereka miliki, tujuannya informasi tersebut akan menghasilkan pengaruh yang besar.

\section{Politik Simbol (Symbolic Politics)}

WALHI juga memainkan kemampuan untuk menggunakan simbol-simbol atau juga tindakan-tindakan maupun sebuah cerita untuk menggambarkan bencana asap yang terjadi di Riau, simbol-simbol tersebut digambarkan WALHI seperti berikut:

\section{Gambar 4. Donasi Bencana Asap}

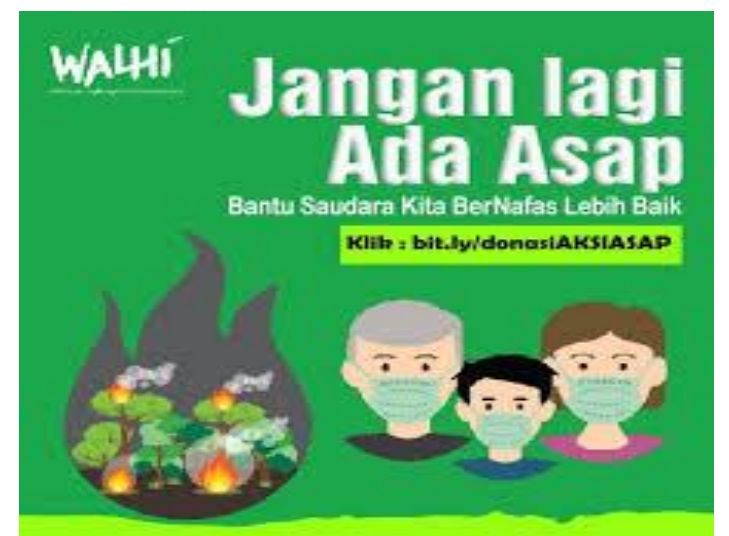

Sumber: Facebook WALHI 2019

\section{Gambar 5. Kampanye Lingkungan}

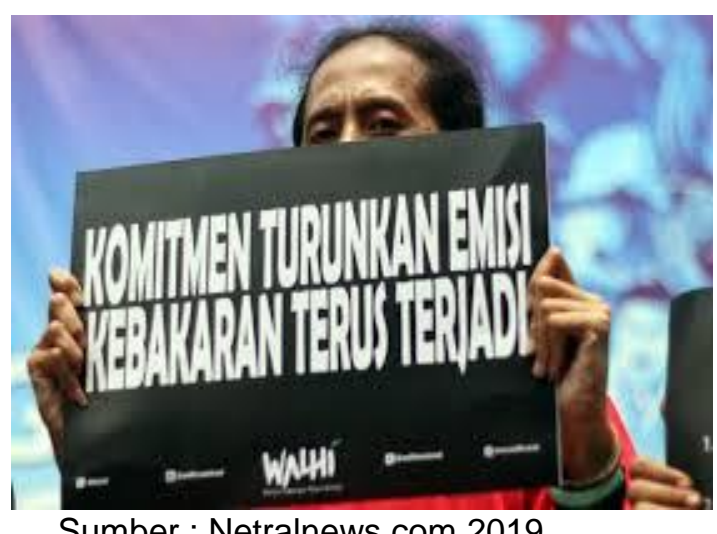

Sumber : Netralnews.com 2019 
Melalui simbol-simbol tersebut WALHI sebagai aktor menggambarkan bagaimana bencana asap akibat dari kebakaran hutan membahayakan bagi warga korban bencana asap di Riau, selain itu tindakan-tindakan WALHI Riau juga seperti demo damai yang dilakukan mereka di Pekanbaru, juga aksi demo mereka di Jakarta yang mengajak semua masyarakat lokal dan internasional untuk ikut serta dalam aksi damai mereka.

\section{Politik Pengaruh (Leverage Politics)}

Sebagai salah satu organisasi yang fokus dalam mengadvokasi masalah lingkungan hidup, WALHI memperkuat dan memperluas jaringanya dengan menggandeng organisasi yang memiliki kekuatan lebih besar, seperti salah satu contoh adalah WALHI Riau mempunyai koalisi dengan WWF-Indonesia, koalisi ini bernama Eyes on The Forest. Terbukti koalisi ini terus mengawasi eksploitasi hutan yang mengakibatkan kebakaran di wilayah Riau.

\section{Politik Akuntabilitas (Accountability Politic)}

WALHI Riau sebagai NGO yang mengawasi lingkungan hidup khususnya di Riau, terus berusaha untuk mengawasi pemerintah untuk menegaskan gerakan mereka sebelumnya WALHI Riau tidak hanya melakukan aksi protes dan simbol-simbol yang mereka sampaikan kepada masyarakat tapi juga WALHI Riau melaporkan perusahaan yang diduga melakukan pembakaran hutan secara besar-besaran yang menyebabkan bencana asap, serupa yang dilansir oleh pekanbaru tribunnews, WALHI Riau melaporkan PT IP, PT IJA, PT CPK, PT SAM ke Polisi Daerah Riau untuk diproses secara hukum. Hal ini dilakukan WALHI Riau sebagai bentuk dari keseriusan mereka dalam bencana asap yang selalu mengawasi korporasi, pemerintah pusat maupun pemerintah Provinsi Riau.

\section{KESIMPULAN}

Kebakaran hutan yang terjadi di wilayah Provinsi Riau berlangsung dari tahun ke tahun mengakibatkan efek buruk ke segala sisi, dimulai dari kesehatan, ekonomi, hingga hubungan Indonesia ke negara tetangga, hal ini membuat NGO mengambil andil untuk memperjuangkan kesetaraan gesekan yang terjadi antara kepentingan masyarakat dan negara.

WALHI Riau mempunyai beberapa cara dalam tindakanya sebagai bagian dari transnational advocacy, yaitu yang pertama dengan cara Information Politic yang dimana WALHI membuat informasi dari media cetak maupun daring untuk menarik perhatian masyarakat lokal maupun internasional, yang kedua yaitu Symbolic Politic, WALHI memberikan simbol-simbol yang berkaitan dengan bencana asap, seperti spanduk-spanduk yang mengambarkan bencana asap, yang ketiga Leverage Politic dimana WALHI menggandeng pihak yang lebih besar sebagai pendukung mereka atas protes-protes terhadap pemerintah terkait bencana asap dan yang keempat Accountability Politic WALHI melaporkan ke Polda Riau beberapa perusahaan yang diduga adalah pelaku pembakar lahan yang mengakibatkan kebakaran hutan hingga menimbulkan bencana asap. 


\section{REFERENSI}

Ardhian, David, Soeryo Adiwibowo, and Sri Wahyuni. 2016. "Peran Dan Strategi Organisasi Non Pemerintahan Dalam Arena Politik Lingkungan Hidup." Jurnal Sosiologi Pedesaan (Desember).

Bryant, Raymond L, and Sinead Bailey. 1997. "A Politicized Environment." In Third World Political Ecology,.London:Routledge

Carter, N. 2007. The Politics of Environment: Ideas, Activism and Policies. Cambridge: Cambridge University Press.

Cholisin, Cholisin. 2015. "Dinamika Lsm Di Indonesia Dan Kontribusinya Terhadap Perkembangan Demokrasi." Informasi 26(1).

E Keck, Margaret, and Kathryn Sikkink. 1998. "Transnational Advocacy Networks in International Politics: Introduction BT - Activists Beyond Borders." In Activists Beyond Borders, Cornell University Press.

Fauzi, Noer, and Herlily. 2005. Memahami Gerakan-Gerakan Rakyat Dunia Ketiga. Insist Press.

Giugni, Marco. 2009. "Political Opportunities: From Tilly to Tilly." Swiss Political Science Review 15: 361-67.

Guadalope M, Rodrigues M. 2004. Global Environtalism and Local Politics: Transnasional Advocacy Networks in Brazil, Ecuador and India. New York (US): State University of Network Press.

Harahap, Rizal. 2016. "Weary of Haze Crisis, Civil Group Files Lawsuit against Government."

thejakartapost.com. https://www.thejakartapost.com/news/2016/03/11/weary-haze-crisis-civil-groupfiles-lawsuit-against-government.html (March 26, 2021).

Ikbar, Yanuar. 2014. "Metodologi \& Teori Hubungan Internasional." Bandung: PT Refika Aditama.

Jordan, Lisa. 2000. "Political Responsibility in Transnational NGO Advocacy." World development 28(12): 2051-65.

King, Marissa. 2004. "Cooptation or Cooperation: The Role of Transnational Advocacy Organizations in the Zapatista Movement." Sociological Focus.

Margaret E, Keck. 1998. "Transnational Advocacy Networks in International Politics: Introduction." In Activist Beyond Borders: Advocacy Networks in International Politcs, New York: Cornell University Press, 1-38.

Meyer, David S, Debra C. Minkoff. 2004. "Conceptualizing Political Opportunity." Social Forces 82(June): 1457-92.

Panjaitan, R. 2015. Dampak, Upaya Dan Harapan Akibat Kebakaran Hutan Tahun 2015 [Makalah]. Hari Pulang Kampung Fakultas Kehutanan IPB; 2015 Nov 7; Bogor Indonesia. Bogor (ID): Fakultas Kehutanan IPB. Bogor.

Park, Susan. 2004. "The Role of Transnational Advocacy Networks in Reconstituting International Organization Identities AND." Seton Hall Journal of Diplomacy and International Relations (Summer/Fall): 79-92.

Persada, Syailendra. 2019. "Cerita Eks Direktur Walhi Riau Yang Jadi Korban Kabut Asap." Tempo.co. https://nasional.tempo.co/read/1250264/cerita-eks-direkturwalhi-riau-yang-jadi-korban-kabut-asap/full\&view=ok (March 26, 2021).

Princen T, Finger M. 1994. Environmental NGOs in World Politics: Linking the Local and the Global. New York (US): Routledge.

Purnomo, $\mathrm{H}$ et al. 2015. "Ekonomi Politik Kebakaran Hutan Dan Lahan Di Riau: Sebuah Pendekatan Analitis [Makalah]." Mencegah Kebakaran Hutan dan Lahan.

Stillerman, Joel. 2003. "Transnational Activist Networks and the Emergence of Labor 
Internationalism in the NAFTA Countries." Social Science History 4(winter): 577-601.

Tarrow, Sidney, Della Porta, Donatella. 2018. "Patterns of Dynamic Multilevel Governance and the Insider-Outsider Coalition." In Transnational Protest and Global Activism, Harvard University Libraries, 151-74.

Tarrow, Sidney. 1994. "Power in Movement." In Power in Movement, Cambridge University Press.

—. 2019. "A Landmark in Scholarly Activism beyond Borders : A Review of Keck and Sikkink's Transnational Advocacy Networks in International and Regional Politics ( ISSJ 159 / 1999 : 89 - 101 )." ISSJ (John Wiley \& Sons Ltd): 1-4. 